Jurnal Caraka Prabu | Volume 01 | No. 01 | Juni 2017

\title{
KEDUDUKAN DAN FUNGSI BADAN SANIRI NEGERI (BADAN \\ PERMUSYAWARATAN DESA) DI KECAMATAN SALAHUTU, KABUPATEN MALUKU TENGAH
}

Oleh : Farah Dessy Tuasamu

\begin{abstract}
Abstrak
Penelitian ini bertujuan untuk mengidentifikasi dan menganalisis Kedudukan dan Fungsi Badan Saniri Negeri dalam proses penyelenggaraan pemerintahan negeri di Negeri Tulehu dan Suli Kecamatan Salahutu, Kabupaten Maluku Tengah, sehingga dapat ditemukan sebab-sebab belum maksimalnya pelaksanaan fungsi Badan Saniri Negeri dalam penyelenggaraan Pemerintahan Negeri.

Penelitian ini menggunakan metode deskriptif kualitatif, dengan teknik pengumpulan data menggunakan observasi dan wawancara untuk untuk mengungkap dan mendeskripsikan permasalahan kedudukan dan fungsi Badan Saniri Negeri sebagai perangkat negeri dalam menyelenggarakan pemerintahan negeri.

Dari hasil penelitian menunjukkan bahwa Badan Saniri Negeri Sebagai Badan Perwakilan yang terdiri atas pemukapemuka masyarakat yang ada di negeri Tulehu dan Suli belum melaksanakan fungsinya secara maksimal dalam proses penyelenggaraan pemerintahan negeri.Untuk menjadikan Badan Saniri Negeri yang efektif dalam menjalankan fungsinya, dalam hal ini dapat menjalankan fungsinya dengan baik yaitu mampu yaitu menampung dan menyalurkan aspirasi masyarakat, pengayom adat istiadat, pelaksana pengawasan terhadap anggaran pendapatan dan belanja negeri serta dalam menetapkan peraturan negeri bersama kepala pemerintah negeriuntuk itu perlu peningkatan inisiatif, prakarsa dan peran aktif Badan Saniri Negeri. Jika kondisi ini dapat terurjud maka penyelenggaraan pemerintahan dan pembangunan di negeri berjalan sesuai dengan harapan dan keinginan masyarakat. Adapun faktor-faktor yang mempengaruhi pelaksanaan fungsi Badan Saniri Negeri adalah 1) Kualitas Anggota badan Saniri Negeri, yang meliputi tingkat pendidikan dari pada anggota Badan Saniri Negeri, pengalaman organisasi dan kondisi sosial ekonomi. 2) Sarana dan Prasarana dalam menunjang penyelenggaraan pemerintahan negeri.
\end{abstract}

Kata Kunci : Fungsi, Badan Saniri Negeri, Perwakilan. 
Kedudukan dan Fungsi Badan Saniri Negeri (Badan

Permusyawaratan Desa) Di Kecamatan Salahutu, Kabupaten Maluku Tengah

Latar Belakang Penelitian

Penyelenggaraan

Pemerintahan Daerah dewasa ini, diarahkan dapat mempercepat terwujudnya kesejahteraan masyarakat melalui peningkatan pelayanan, pemberdayaan dan peran serta masyarakat, yang diharapkan mampu meningkatkan daya saing dengan memperhatikan prinsip demokrasi, pemerintahan, keadilan, keistimewaan dan kekhususan serta potensi dan keanekaragaman daerah dalam sistem Negara Kesatuan Republik Indonesia.

Pemerintahan Daerah dalam rangka meningkatkan efisiensi dan efektivitas penyelenggaraan Daerah, perlu memperhatikan hubungan antara susunan Pemerintahan Pusat dan antar Pemerintahan Daerah, potensi dan keanekaragaman daerah serta aspek hubungan keuangan, pelayanan umum, pemanfaatan sumber daya alam dan sumber daya lainnya secara adil dan merata. Disamping itu perlu diperhatikan pula peluang dan tantangan dalam persaingan global dengan memanfaatkan perkembangan pengetahuan dan teknologi, agar Pemerintah Daerah dapat menjalankan perannya sesuai dengan fungsi dan wewenang yang diberikan dalam penyelenggaraan

pemerintahan baik oleh pemerintah pada tingkat pusat, daerah maupun pemerintahan di tingkat desa.

Dalam Undang-Undang No 32 Tahun 2004 tentang Pemerintah Daerah, dan Peraturan Pemerintah No 72 Tahun 2005 tentang Desa, disebutkan bahwa :

"Desa atau yang disebut dengan nama lain, selanjutnya disebut Desa, adalah kesatuan masyarakat hukum yang memiliki batas-batas wilayah, berwenang untuk mengatur dan mengurus kepentingan masyarakat setempat berdasarkan asal-usul dan adat istiadat setempat yang di akui dan dihormati dalam sistem pemerintahan Negara Kesatuan Republik Indonesia".

Desa bagi daerah Maluku, khususnya Maluku Tengah dan Pulau Ambon lazimnya disebut "Negeri", yang didalamnya termasuk Pemerintah Negeri. dengan 
diberlakukannya UndangUndang No 32 Tahun 2004, maka lembaga-lembaga adat seperti Saniri memiliki pengakuan terhadap eksistensinya yang terlegitimasi dengan nama Badan Saniri Negeri atau Badan Permusyawaratan Negeri. Meski demikian jika ditinjau dari perspektif sosial politik, ada beberapa hal yang secara fundamental cukup mempengaruhi tugas, peran dan fungsi dari Badan Saniri, misalnya tentang rekruitmen anggota, pimpinan lembaga saniri serta proses penyelenggaraan fungsi pemerintahan.

Di Maluku Desa/Negeri dikepalai oleh seorang Raja (Kepala Pemerintahan Negeri), Raja dibantu oleh Badan Saniri Negeri. Berdasarkan Peraturan Daerah Kabupaten Maluku Tengah No. 04 tahun 2006 tentang Pedoman Penataan Badan Saniri Negeri, disebutkan bahwa:

"Saniri Negeri adalah lembaga atau badan yang merupakan perwujudan demokrasi dalam penyelenggaraan Pemerintah Negeri, berfungsi sebagai badan legislatif yang bersama-sama Kepala Pemerintahan Negeri (Raja) membentuk peraturan negeri, megawasi pelaksanaan tugas dari Kepala
Pemerintah Negeri serta merupakan badan yang mendampingi Kepala Pemerintahan Negeri dalam memimpin negeri, sesuai tugas dan wewenang yang dimilikinya".

Badan Saniri Negeri pada saat ini tidak berfungsi optimal dalam menyalurkan aspirasi masyarakat. kondisi ini terjadi karena rendahnya tingkat kehadiran dalam setiap rapat yang di selenggarakan oleh Pemerintah Negeri, salah satu penyebabnya adalah selain kesibukan dan kepentingan pribadi, para anggota Badan Saniri Negeri juga memerlukan biaya untuk hidup mereka dan keluarganya yang sama sekali tidak terlalu banyak mengharapkan dan menggantungkan diri dari uang kehormatan atau honor sebagai anggota Badan Saniri Negeri yang belum tentu ada anggarannya. Tingkat kehadiran anggota Badan Saniri Negeri yang rendah dalam setiap rapat menyebabkan penyusunan program kerja Negeri yang tidak responsif sesuai dengan keinginan dan aspirasi masyarakat. Lemahnya pengawasan terhadap sumbersumber pendapatan asli Negeri dan kurangnya kepedulian anggota Saniri Negeri dalam pelestarian dan pemeliharaan adat istiadat seperti Badan 


\begin{abstract}
Saniri Negeri kehilangan fungsinya sebagai "Saniri Kewang"1, yang berwenang mengadili pelanggaranpelanggaran terhadap "Sasi"2. Apabila tidak mendapat pengawasan oleh Badan Saniri Negeri maka terjadi kerawanan sosial seperti pencurian dan pengrusakan terhadap sumber daya alam yang ada di Negeri.

Sebagian masyarakat

fungsi Badan Saniri Negeri tidak berjalan maksimal.

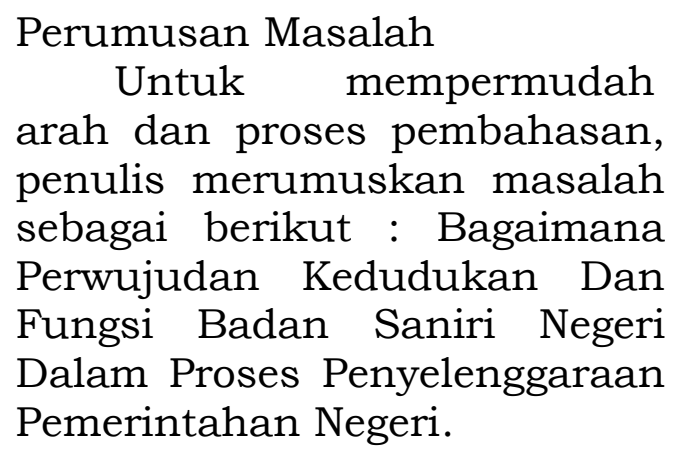
arah dan proses pembahasan, penulis merumuskan masalah sebagai berikut : Bagaimana Perwujudan Kedudukan Dan Fungsi Badan Saniri Negeri Dalam Proses Penyelenggaraan Pemerintahan Negeri. juga menilai bahwa Badan Saniri yang terbentuk selama ini bukan murni melalui suatu meknisme adat tetapi merupakan penunjukan terhadap orang-orang terdekat dengan bapak Raja (Kepala Pemerintah Negeri), anggota Badan Saniri Negeri juga dinilai tidak konsisten terhadap setiap peraturan atau kebijakan yang telah dihasilkannya. Mengakibatkan banyak Peraturan Negeri yang dianggap tidak berjalan. Adanya ketidakpercayaan antara anggota satu dengan yang lainnya sehingga menyebabkan pelaksanaan

\footnotetext{
${ }^{1}$ lembaga adat yang dikuasakan sebagai pengelola sumber daya alam dan ekonomi masyarakat.

${ }^{2}$ Adat istiadat untuk melindungi sumber daya alam serta hasil hutan dan kebun yang biasanya dilakukan beberapa larangan untuk memanen hasil tanaman tersebut sampai sampai batas waktu yang telah ditentuan oleh kewang sebagai penanggung jawab sumber daya alam Negeri.
}

Maksud dan Kegunaan
Penelitian
Maksud penelitian ini
yaitu untuk mengidentifikasi
dan menganalisis Kedudukan
dan Fungsi Badan Saniri
Negeri Dalam
Penyelenggaraan Proses
Pemerintahan Negeri.

\section{Kerangka Teori}

\section{Konsep Perwakilan (Representative) \\ Inti dari fungsi dan peran} lembaga perwakilan adalah bagaimana membuat aspirasi rakyat atau "yang diperintah" dapat diakomodasikan dan diartikulasikan dalam berbagai kebijakan yang dirumuskan dan dibuat oleh lembaga perwakilan tersebut. Hal ini merupakan konsekuensi logis dari suatu pemerintahan yang didasarkan atas prinsipprinsip demokrasi yaitu "dari, oleh dan untuk rakyat".

Perwakilan berasal dari kata Representativeness (bahasa inggris) dari kata 
dasar Represent yang berarti to serve to express, stand for, yang menunjukan, mewakili, menurut Ndraha (2003 : 108109) keterwakilan adalah fenomena politik lebih ekstrim dikatakan simbol demokrasi yaitu "dari", "Oleh", dan "untuk", rakyat, diemban oleh orang-orang terpilih atau ditunjuk, dan dilembagakan menjadi badan-badan perwakilan seperti Fraksi, DPR, Senat, majelis, MPR dan sebangsanya, oleh karena itu menurutnya mekanisme perwakilan lebih efektif ketimbang pada populasi. Lembaga seperti ini menurut Ndraha (2003 : 109):

Diberi nyawa (kuasa untuk atas nama yangdiperintah berinteraksi dengan pemerintah oleh constituent, mempunyai kehendak sendiri dan dari sini, kepentingan sendiri dan terikat pada struktur. Prilakunya berubah. Ia bisa menumbangkan pemerintah, bisa bersekongkol dengan pemerintah (eksekutif), dan bisa berbalik melawan aspirasi masyarakat yang seharusnya diwakilinya. Makna Pemerintahan Perwakilan dapat dikemukakan dari berbagai pendekatan menggunakan dengan disiplin ilmu atau multi- disiplin dan transdisiplin. Ndraha (2000) mengemukakan konsep Pemerintahan Perwakilan dapat dijelaskan dari konsep Governance Relatioship yaitu terjadinya hubungan pemerintahan diterangkan melalui berbagai pendekatan, mulai dari pendekatan parlementologi, ilmu politik, sosiologi dan antropologi.

Dari pandangan yang dikemukan oleh Ndraha di atas, dapat dimaknai bahwa lembaga merupakan lembaga yang berperan aktif dalam menjalankan tugasnya sebagai penghubung antara masyarakat dan pemerintah desa agar pembangunan dapat dilaksanakan secara bersamasama. Sehingga lembaga perwakilan harus mempunyai kemampuan dan kewajiban dalam mengakomodasikan dan mengartikulasikan aspirasi masyarakat, namun bisa terjadi penyimpangan dalam menjalankan fungsi hakiki dari lembaga perwakilan rakyat dalam mengakomodasikan dan mengartikulasikan aspirasi rakyat.

Pito

(2006:102-103) mengemukakan perwakilan lainnya dari beberapa ahli dalam Andrianus (102-103), yang pada intinya mengemukakan bahwa:

"Perwakilan diartikan sebagai proses 


\begin{abstract}
hubungan diantara dua pihak, yaitu wakil dengan terwakili dimana wakil memegang kewenangan untuk bertindak sesuai dengan kesepakatan yang dibuatnya dengan terwakili, selain itu wakil harus mampu membuat kebijakan menyangkut kepentingan sesuai kepentingan terwakil”.

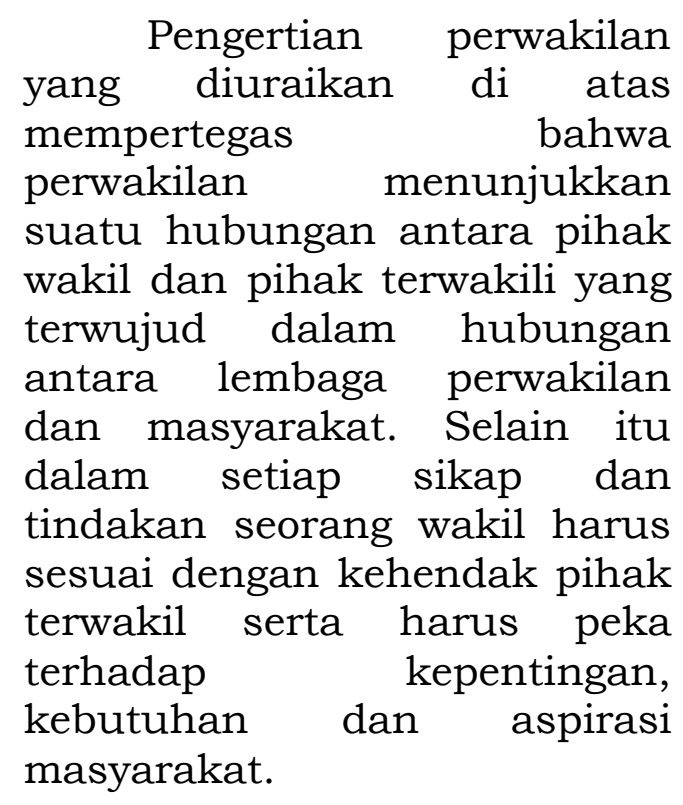

2. Kedudukan dan Fungsi Badan Permusyawaratan Desa (BPD)

Badan Permusyawaratan

Desa (BPD) adalah unsur lembaga dalam penyelenggaraan

pemerintahan desa. Peran BPD sangat penting, karena sebagai unsur lembaga yang paling dekat dengan masyarakat.oleh karena itu, sesuai dengan tujuan terbentuknya BPD diharapkan dapat terwujudnya suatu proses demokrasi yang baik di mulai dari sistem pemerintahan terkecil yaitu desa.

Badan Permusyawaratan Desa (BPD) merupakan lembaga perwujudan demokrasi dalam penyelenggaraan

pemerintahan desa. Badan Permusyawaratan Desa (BPD) dapat dianggap sebagai "parlemen-nya" desa. Di era otonomi daerah ini pemerintah daerah diberi keleluasaan untuk mengurus daerahnya sesuai dengan prinsip demokrasi. Dalam mewujudkan prinsip demokrasi tersebut maka di dalam pemerintahan desa dibentuklah suatu badan yang dapat mewujudkan aspirasi dari masyarakat desa. Badan tersebut dinamakan Badan Permusyawaratan Desa atau yang sering kita sebut dengan BPD.

BPD merupakan salah satu bentuk pemerintahan perwakilan yang ada di desa. Menurut Ndraha (dalam Napitupulu, 2007: 15) menjelaskan bahwa :

Konsep pemerintahan perwakilan dapat dijelaskan dari konsep Governance Relationship yaitu terjadinya 


\begin{abstract}
hubungan pemerintahan diterangkan melalui berbagai pendekatan, mulai dari pendekatan Parlementologi, ilmu politik, sosiologi, dan antropologi.

Pemerintahan
\end{abstract}

perwakilan merupakan lembaga dalam menjalankan tugasnya sebagai penghubung antara masyarakat dan pemerintah desa agar pembangunan dapat dilaksanakan secara bersamasama. Hal tersebut sejalan dengan Napitupulu (2007 : 14) yang menyatakan inti dari konsep pemerintahan perwakilan itu adalah "rakyat bersama-sama membentuk negara dan mengisi jabatanjabatan negara serta menyusun suatu sistem pemerintahan melalui mekanisme pemilihan tertentu."

BPD selaku Badan

Perwakilan atau sebagai lembaga legislatif yang memiliki tugas sebagai lembaga pengawas dalam hal pelaksanaan peraturan desa sangat berperan dalam kelancaran pelaksanaan pembangunan di desa itu sendiri. Demikian juga BPD sejajar dan menjadi mitra pemerintah desa. Adapun fungsinya yaitu mengayomi adat istiadat, membuat peraturan desa, menampung dan menyalurkan aspirasi masyarakat, serta melakukan

\begin{abstract}
pengawasan
terhadap

penyelewengan pemerintah desa. (Suhartono, 2000: 158)

Diantara fungsi badan

legisasi seperti BPD yang paling penting adalah menentukan kebijakan dan membuat perundangundangan serta mengontrol badan eksekutif supaya semua tindakan badan eksekutif sesuai dengan kebijakankebijakan yang telah ditetapkan (Budiardjo, 2000 : 182).
\end{abstract}

Objek dan Metode Penelitian Objek Penelitian ini adalah Anggota Badan Saniri Negeri, Aparatur Pemerintah Negeri, Tokoh Adat, dan Masyarakat. Sedangkan metode penelitian adalah Metode deskriptif yang dapat mengarahkan penulis dalam melakukan penelitian dan pengamatan dengan menggunakan pendekatan kualitatif.

Adapun teknik penentuan informan yang digunakan adalah purposive (pengambilan informan berdasarkan tujuan). Penentuan informan dalam penelitian ini berdasarkan objek yang diteliti dan berdasarkan keterkaitan informan tersebut dengan penelitian. Sedangkan teknik pengumpulan data yang dipakai peneliti yaitu observasi , wawancara dan studi dokumentasi. Teknik 
analisis data yang sesuai dengan penelitian ini adalah analisis deskriptif kualitatif.

\section{Hasil Dan Pembahasan}

\section{Fungsi}

Permusyawaratan

Badan atau Badan Saniri Negeri dalam Melestarikan Adat Istiadat.

Di

umumnya, struktur masyarakat yang demokratis, di mana ada dewan-dewan adat (tokoh adat) sebagai lembaga pengatur pengemban dan penyelamat nilai-nilai adat. Kehidupan lingkungan hidup mempunyai standar nilai-nilai tersendiri, tetapi pola umum lingkaran hidup manusia menurut pandangan hidup/kepercayaan pada masa dahulu kala di kuasai oleh suatu kekuatan diluar kemampuan manusia itu adalah sama diseluruh dunia. Itulah sebabnya terdapat keseragaman/kesamaan

dalam lingkungan geografis yang berbeda.

Peran adat istiadat sejak dulu sampai sekarang ini, adat istiadat masih terpelihara dalam mengatur kehiduan masyarakat dengan tidak mengurangi bahwa masyarakat masih tetap mematuhi peraturan perundang-undangan dan tetap menjalankan syariat berperan strategis dalam kehidupan nasional. Adat istiadat dan kebiasaan masyarakat ini merupakan modal bangsa dalam menentukan corak pergaulan bangsa Indonesia dengan bangsa lain. Paling sedikit adat istiadat ini berfungsi sebagai penyaring budaya asing yang masuk ke Indonesia, khususnya sejalan dengan perkembangan teknologi informasi yang semakin pesat lajunya.

Di Kecamatan Salahutu dahulunya stuktur kelembagaan adat di Negeri terus eksis dan berperan secara optimal hingga mampu menciptakan keserasian dan keharmonisan dalam kehidupan sosial masyarakat. Salah satu lembaga adat yang kehilangan perannya adalah Badan Saniri Negeri. Sebelum Undang-Undang ini diberlakukan dalam melaksanakan tugas-tugasnya Raja dibantu oleh Badan Saniri Negeri. Badan Saniri Negeri adalah lembaga adat yang berperan mengayomi adat istiadat dan hukum adat. Saniri Negeri berperan membantu Raja atau Kepala Desa dalam menyelesaikan setiap perselisihan di lingkup negeri atau dusun.

Perlu ditambahkan bahwa, pada saat itu peran Raja dalam penyelesaian permasalahan publik, baik masalah tanah, konflik dalam keluarga, maupun masalah 
lainnya, hanya sebagai eksekutor dalam memutuskan suatu persoalan dan keputusan Raja ni sangat ditaati oleh masyarakat, namun proses diskusi, negosiasi serta mediasi sebelum keputusan itu dibuat ada di tangan Badan Saniri Negeri melalui pertemuan yang dilaksanakan di Balai negeri (Baeleo), bagaimana proses komunikasi yang dibangun oleh Badan Saniri Negeri untuk mendudukan persoalan yang dihadapi oleh dua pihak yang bersengketa, bagaimana Badan Saniri Negeri menghasilkan keputusankeputusan dalam forum komunikasi internal Badan Saniri Negeri itu untuk upaya penyelesaian permasalahan yang dihadapi, hingga bagaimana Bagaiman Saniri Negeri melakukan pemetaan persoalan yang lebih besar, jika perlu pihak mana saja perlu dilibatkan dalam penyelesaian persoalan tersebut.

Adapun pengakuan

Negara terhadap per-sekutuan masyarakat adat yang ada di Kecamatan Salahutu sebagaimana tercantum dalam penjelasan atas UndangUndang No 23 Tahun 2014 telah membuka ruang untuk banngkitnya kembali lembagalembaga adat yang penetapannya dilakukan berdasarkan Peraturan Daerah
Provinsi Maluku No 14 Tahun 2005 tentang Penetapan Kembali Negeri sebagai kesatuan Masyarakat Hukum Adat dalam Wilayah Pemerintahan Provinsi Maluku yang merupakan aturanaturan turunan dari UndangUndang tersebut Yang kemudian dijabarkan lagi lebih detail dalam Peraturan Daerah Kabupaten Maluku Tengah.

Kemudian yang menjadi persoalan selanjutnya adalah bagaimana Peraturan Daerah tersebut ditindaklanjuti hingga pada tingkat desa melalui Peraturan Negeri, dimana diharapkan dalam peraturan negeri tersebut dapat dijabarkan tersebut dapat dijabarkan lebih jauh mengenai kedudukan formal masing-masing lembaga yang ada dalam struktur pemerintahan negeri termasuk Badan Saniri yang sebelumnya hanya mendapatkan pengakuan secara sepihak oleh masyarakat saja sehingga pada akhirnya juga dapat diwujudkan menjadi suatu tatanan hukum yang diakui oleh Negara juga secara formal.

Pemberlakuan

mekanisme adat dalam penyelesaian persoalan yang ada dalam masyarakat dengan sendirinya telah menimbulkan suatu perubahan sikap dari masing-masing pihak di satu 
sisi Badan Saniri Negeri seperti memperoleh kekuatan hukum dalam menjalankan kedudukannya sebagai pimpinan masyarakat yang sudah sekian ini tidak pernah dilakoni.

Keadaan demikian menyebabkan adanya disintegrasi antara lembaga adat dengan lembaga penegak hukum formal, memang pada masa lampau dimana lembaga adat memiliki legitimasi secara adat untuk melakukan upaya penyelesaian persoalanpersoalan yang ada dalam masyarakatnya namun pada saat ini telah ada begitu banyak perubahan-perubahan yang berlangsung dalam masyarakat, sehingga untuk menyesuaikan peran dari masing-masing lembaga formal maupun lembaga adat adalah merupakan tanggung jawab penguasa dalam hal ini Pemerintah untuk menciptakan suatu kerja sama yang terpadu antara lembaga formal dan lembaga adat dalam suatu mekanisme solid demi ketentraman kehidupan masyarakat.

Dengan demikian, diharapkan Badan Saniri Negeri benar-benar menjalankan fungsi pengayom adat sehingga adat istiadat dan tradisi negeri yang telah terpendam dapat di data dan dipraktekan kembali dalam kehidupan sehari - hari. Agar pranata -pranata adat bisa terlihat dari generasi ke generasi maka upaya yang harus dilakukan adalah penataan kelembagaan yang ada di negeri khususnya Suli dan Tulehu. Dengan menumbuhkan kembali semangat untuk menghidupkan dan mempraktekkan adat istiadat, melalui Peraturan negeri terkait pelestarian adat istiadat dan perubahanperubahan dan pembenahan di tingkat negeri oleh Badan Saniri Negeri dan Pemerintah Negeri.
2. Fungsi Badan Permusyawaratan Desa atau Badan Saniri Negeri dalam Menampung dan Menyalurkan Aspirasi Masyarakat.

Keberadaan Badan

Saniri Negeri diharapkan dapat membawa pembaharuan dalam penyelenggaraan pemerintahan dan pelaksanaan pembangunan di negeri. Badan Saniri Negeri harus dapat berjalan sejajar dengan Pemerintah Negeri dalam wujud kemitraan. Sebagai badan perwakilan yang terdiri atas pemukapemuka masyarakat yang ada di negeri, Badan Saniri Negeri mempunyai fungsi antara lain menampung dan menyalurkan aspirasi masyarakat negeri. Untuk itu perlu peningkatan inisiatif, prakarsa dan peran aktif anggota Badan Saniri 
Negeri. Jika kondisi ini dapat terwujud, maka penyelenggaraan

pemerintahan di negeri dapat berjalan sesuai dengan harapan dan keinginan masyarakat.

Menurut Eisinger dalam Pito (2006 : 111), menyatakan bahwa "pemahaman mengenai sitem perwakilan tentunya memberikan gambaran bahwa perwakilan individu harus memahami aspirasi, nilai kepencayaan dan sikap-sikap masyarakat". Oleh karena itu menurutnya sistem perwakilan harus mewujudkan fungsinya secara nyata daam penyelenngaraan kehidupan bermasyarakat dan bernegara. Untuk mengetahui pelaksanaan fungsi Badan Saniri Negeri, maka terlebih dahulu harus mengetahui tingkat aktivitas yang dilakukan oleh Badan Saniri Negeri itu sendiri. Kegiatan yang dilakukan oleh Badan Saniri Negeri ,merupakan aktualisasi dari pelaksanaan fungsi Badan Saniri Negeri. Sebagaimana telah sebelumnya dijelaskan bahwa Badan Saniri Negeri berperan untuk menyerap dan menyalurkan berbagai aspirasi masyarakat serta memperjuangkan agar bisa terwujud dalam kebijakan Pemerintah Negeri, selain dari pada itu Badan Saniri Negeri diberi kewenangan untuk membuat Peraturan Negeri, pengawasan terhadap penyelenggaraan

pemerintahan negeri dan pengayom adat istiadat.

Fungsi perwakilan dari Badan Saniri Negeri dilihat dari dua aspek yaitu secara kuantitas diantaranya proporsi banyaknya anggota Badan Saniri Negeri, latar belakang pekerjaan atau profesi yang ditekuni oleh mereka sebelum duduk menjadi anggota Badan Saniri Negeri. Sementara itu ditinju dari aspek kualitas keterwakilan, anggota Badan Saniri Negeri di Kecamatan Salahutu harus mampu mewakili aspirasi yang berkembang di tengah-tengah masyarakat. Anggota Badan Saniri Negeri dianggap sebagai representasi masyarakat luas, kualitas anggota Badan Saniri Negeri dapat dilihat dari prilaku dan sikap anggota Badan Saniri Negeri, putusanputusan, saran, maupun tindakan lainnya pada saat membahas berbagai aspirasi masyarakat dengan pemerintah negeri.

Agar Badan Saniri
Permusyawaratan Negeri yang dijadikan sebagai wadah bagi aspirasi masyarakat, wadah aspirasi yang dimaksud disini yaitu sebagai tempat dimana keinginan atau aspirasi masyarakat disampaikan dapat tersalurkan maka Badan Saniri Negeri perlu 
mengadakan pertemuan setiap saat dengan masyarakat disekitarnya agar dapat mengetahui apa yang menjadi keinginan dari masyarakat. Hasil observasi dan penelitian penulis, tugas dan wewenang Badan Saniri Negeri dalam menggali, menampung dan menyalurkan aspirasi masyarakat telah berjalan sesuai dengan tugas dan wewenang yang ada pada Peraturan Daerah. Namun dalam implementasinya belum begitu dirasakan manfaat keberadaan Saniri Negeri di tengah-tengah masyarakat, karena masih banyak keluhan dari masyarakat yang belum terealisasi dengan baik, contoh keluhan-keluhan yang disampaikan oleh masyarakat kepada Saniri Negeri di negeri Tulehu dan Suli sesuai penelitian penulis, yaitu :

a. Masalah menyangkut kinerja Pemerintah Negeri yang harus ditingkatkan.

b. Masalah pemberantasan minum keras agar ada Peraturan Negeri yang mengatur tentang larangan minuman keras.

c. Semua kegiatan menyangkut kekuangan negeri harus ada laporan tertulis.

d. Masalah Raskin yang sampai sekarang masih terjadi penyelewengan dalam pembagian.

Sebagai suatu lembaga di negeri yang tumbuh dari internal wilayah untuk mengumpulkan berbagai keinginan dan harapan masyarakat serta menjadi wadah bagi setiap partisipasi masyarakat dalam pembangunan guna memadukan pelaksanaan berbagai kegiatan pembangunan negeri, baik berbentuk prakarsa maupun aspirasi masyarakat swasembada gotong royong masyarakat dalam aspek kehidupan dan penghidupan dalam rangka mewujudkan ketahanan nasional, meliputi ranah idiologi, politik ekonomi, sosial budaya, agama dan pertahanan dan keamanan.

\section{Fungsi Badan \\ Permusyawaratan Desa atau Badan Saniri Negeri Menetapkan Peraturan Negeri.

$$
\text { Peraturan Desa atau }
$$

Negeri (Perneg), merupakan bentuk peraturan perundangundangan yang relatif baru, dalam kenyataan dilapangan belum begitu popular dibandingkan dengan bentuk peraturan perundangundangan yang lain. Karena masih relatif baru dalam praktek-praktek penyelenggaraan pemerintahan di tingkat 
negeri. Seringkali Peraturan Negeri ini diabaikan bahkan masih banyak dari Pemerintah Negeri dan bahkan masyarakat mengabaikan negeri negeri, Sebagai dasar penyelenggaraan urusan pemerintahan ditingkat negeri. Rancangan Peraturan Negeri merupakan ide-ide, berbagai bahan untuk dibahas dalam menetapkan suatu Peraturan Negeri. Rancangan Peraturan Negeri dapat diajukan oleh pemerintah negeri melalui Kepala Pemerintah Negeri (Raja) maupun oleh Badan Saniri Negeri. Baik Peraturan Negeri yang berasal dari Pemerintah Negeri maupun dari Badan Saniri Negeri, disusun sesuai dasar penyusunannya. Penyusunan Peraturan Negeri yang disusun oleh Pemerintah Negeri di Kecamatan Salahutu didasarkan pada dua kategori yaitu :

\section{a. Kebutuhan negeri \\ b. Data negeri}

Fungsi legislasi ini tampak pelaksanaannya oleh Badan Saniri Negeri di dua negeri Tulehu dan Suli memilki kesamaan dalam proses perumusan peraturan negeri, terdapat 3 (tiga) tahapan di dalam proses pembuatan peraturan negeri yakni :
1) Tahap Inisiasi
2) Tahap Sosio Politis
3) Tahap Yuridis

Fungsi legislasi Badan Saniri Negeri belum dapat berjalan secara maksimal, hal ini ditunjukan dengan kurang komprehensipnya Badan Saniri Negeri dalam membingkai peraturanperaturan negeri yang masih bersifat konfensional atau kebiasaan kedalam peraturan tertulis.

Proses yang dilakukan Badan Saniri Negeri dalam menetapkan Peraturan Negeri adalah sebagai berikut :
a. Kepala Pemerintah Negeri (Raja) menetapkan Peraturan Negeri setelah mendapatkan persetujuan dari Badan Saniri Negeri.

b. Peraturan Negeri ditandatangani oleh Kepala Pemerintah Negeri bersama ketua Badan Saniri Negeri.

lembaga legislatif, bagi Pemerintah Negeri merupakan lembaga yang memiliki peranan yang penting dalam Pemerintahan Negeri terutama berkaitan dengan proses penyusunan Peraturan Negeri sehingga jumlah anggota yang hadir dalam setiap pertemuan untuk merumuskan dan menetapkan sebuah rancangan Peraturan Negeri sangat mempengaruhi.

Kecamatan Salahutu menghadapi beberapa kendala dalam proses penyusunan 
Peraturan Negeri adalah masalah intensitas kehadiran anggota Badan Saniri Negeri. Konsekuensi kesibukan para anggota Badan Saniri Negeri dalam pekerjaan primer sehari-hari mengakibatkan terbengkalainya tugas-tugas sebagai anggota Badan Saniri Negeri. Padahal menurut penulis lembaga ini sangat vital untuk menentukan maju mundurnya suatu pemerintahan negeri. Badan Saniri Negeri sebagai lembaga legislatif saat ini kurang kritis terhadap Pemerintah Negeri, hal ini mengakibatkan pencapaian dari Peraturan Negeri terutama yang menyangkut masalah kepentingan masyarakat kurang dapat dicapai secara maksimal.

Setelah Peraturan Negeri ditetapkan oleh Kepala Pemerintah Negeri (Raja) maka Peraturan Negeri tersebut sudah dapat di masyarakat, dan agar warga masyarakat tahu kalau ada Peraturan Negeri yang mengikat di negeri maka perlu adanya sosialisasi Peraturan Negeri maka perlu diadakan rapat-rapat di dusun-dusun atau pada saat pertemuan di tingkat negeri.
4. Fungsi

Badan

Permusyawaratan Desa atau Badan Saniri Negeri dalam Melakukan Pengawasan.

Badan Saniri Negeri mempunyai fungsi membuat dan menetapkan peraturan negeri bersama-sama dengan Pemerintah Negeri, selain itu Badan Saniri Negeri juga berfungsi mengawasi jalannya Pemerintahan Negeri, fungsi bidang pengawasan ini meliputi pengawasan terhadap Peraturan Negeri, pengawasan terhadap Anggaran Pendapatan dan Belanja Negeri, dan pengawasan terhadap keputusan Kepala Pemerintah Negeri (Raja).

\section{Menurut Djajoesman} (dalam Sophater, 2008 : 24) merumuskan bahwa arti pengawasan (kontrol) adalah suatu proses untuk menentukan hubungan antara yang diharapkan dari perencanaan dengan hasil kenyataan yang didapat, serta mengambil tindakan yang perlu secara sah guna memperbaiki segala sesuatu yang menyimpang dari rencana.

Dari pengertian diatas bahwa pengawasan terhadap pemerintah adalah upaya untuk menghindari terjadinya kekeliruan-kekeliruan, baik disengaja maupun tidak disengaja. Fungsi pengawasan 
$\begin{array}{lr}\text { yang dilakukan oleh Badan } \\ \text { Saniri Negeri } & \begin{array}{r}\text { merupakan } \\ \text { terhadap }\end{array} \\ \text { penilaian } & \text { peraturan- } \\ \text { pelaksanaan } & \text { peraturan yang dijalankan } \\ \text { oleh Pemerintah Negeri. }\end{array}$

Di dalam pelaksanaan

Peraturan Negeri, Badan

Saniri Negeri juga

melaksanakan kontrol atau pengawasan terhadap

peraturan-peraturan Negeri

dan peraturan Kepala

Pemerintah Negeri (Raja).

Pelaksanaan pengawasan

Peraturan negeri dan

Peraturan Kepala Pemerintah

Negeri yang dimaksud disini yaitu

pengawasan terhadap

Anggaran Pendapatan Belanja Negeri yang dijadikan sebagai Peraturan Negeri dan juga pengawasan terhadap keputusan Kepala Pemerintah Negeri.

Terkait efektivitas

pengawasan Badan Saniri

Negeri dalam mengawasi jalannya Peraturan Negeri, dibutuhkan juga partisipasi dan kerja sama dari seluruh komponen masyarakat. Badan Saniri Negeri melakukan pengawasan terhadap jalannya peraturan negeri di masyarakat. Adapun hal-hal yang dilakukan oleh Badan Saniri Negeri terhadap penyimpangan peraturan yaitu memberikan teguran-teguran secara langsung ataupun arahan-arahan. Apabila hal tersebut tidak dapat diselesaikan, maka Badan Saniri Negeri akan membahas masalah ini bersama dengan pemerintah negeri dan tokohtokoh masyarakat lainnya.

Dalam pelaksanaan fungsi kontrol itu sendiri, masih ada sebagian anggota Badan Saniri Negeri belum mengetahui dengan baik tentang fungsi pengawasan yang dilakukan terhadap pemerintah negeri, masih ada sebagian anggota Badan Saniri Negeri yang belum maksimal dalam melaksanakan fungsi kontrolnya. Ini terlihat dari banyak keputusan kepala pemerintah negeri yang tidak dijalankan dan disosialisasikan kepada masyarakat, sehingga banyak pelanggaran-pelanggaran yang terjadi dimasyarakat akibat kurangnya pengetahuan masyarakat. Badan saniri negeri lebih bergerak pasif dan menunggu sehingga dirasakan kurang kritis terhadap keadaan yang ada. Hal ini dipahami sebagai konsekuensi dari kesibukan para anggota Saniri Negeri dibidang profesi sehari-hari sehingga perhatian terhadap lembaga Saniri Negeri menjadi berkurang.

Pelaksanaan fungsi dari pada Badan Saniri Negeri belum mampu memuaskan sebagian besar masyarakat di kedua negeri tersebut disebabkan oleh faktor-faktor yang mempengaruhi dan 
membentuk sikap dan prilaku anggota Badan Saniri Negeri dapat diketahui bahwa minimnya kualitas anggota serta sarana dan prasarana yang tersediapun sangat mempengaruhi pelaksanaan fungsi Badan Saniri Negeri dalam penyelenggaraan pemerintahan negeri.

Faktor pengalaman juga mempengaruhi kemampuan seseorang. Pengalaman yang banyak akan sangat mempengaruhi kemampuan anggota badan saniri negeri dalam meaksanakan fungsinya, menurut kedudukan badan saniri negeri sebagai wakil rakyat di negeri, seharusnya mereka adalah orang-orang yang memiliki pengalaman dalam bidang organisasi kemasyarakatan dan organisasi pemerintah, sehingga akan memberikan kemampuan kepadanya untuk memahami aspirasi masyarakat yang terus berkembang.

Faktor kondisi sosial ekonomi anggota Badan Saniri Negeri, adalah salah satu faktor yang mempengaruhi pelaksanaan fungsi Badan Saniri Negeri. Kondisi sosial ekonomi seorang anggota Badan Saniri Negeri berpengaruh terhadap pergeseran prilaku anggota Badan Baniri Negeri yang sebelumnya sangat memperhatikan aspirasi masyarakat yang diwakilinya untuk dijadikan sebagai suatu kebijakan Pemerintah Negeri. Adanya pemberian insentif atau pendapatan juga menjadi faktor yang berpengaruh dalam memacu kinerja Badan Saniri Negeri untuk menjadi lebih baik dan merupakan wujud penghargaan dan kepedulian pemerintah terhadap Badan Saniri Negeri. Pemberian insentif yang dinilai belum memadai bagi anggota Badan Saniri Negeri terkadang menjadi penghambat dalam meningkatkan kinerja. Berdasarkan data yang diperoleh peneliti diketahui bahwa insentif yang diberikan oleh pemerintah masih sangat minim. Hal inilah yang terkadang membuat anggota menomor duakan tugasnya. Insentif yang diberikan masih jauh untuk memenuhi kebutuhan keluarga kami sehingga kami masih perlu untuk mencari pekerjaan sampingan.

juga $\begin{array}{rr}\text { Sarana dan } & \text { prasarana } \\ \text { menjadi } & \text { faktor }\end{array}$ berpengaruh demi kelancaran kinerja Badan Saniri Negeri. Fasilitas operasional atau sarana dan prasarana adalah seluruh jenis peralatan, sebagai perlengkapan aktivitas dan fasilitas pendukung lainnya. Prasarana merupakan wahana dimana segala jenis peralatan dimaksud melakukan kegiatan. Oleh 
karena itu sarana dan prasarana sangat dibutuhkan sebagai alat pendukung utama dalam proses kegiatan untuk mencapai tujuan organisasi yang telah ditentukan sebelumnya. Tidak adanya tempat khusus bagi Saniri Negeri sebagai pusat kegiatan administratif lembaga legislatif lainnya.

Realitas ini dapat di telusuri di dalam implementasi kedudukan dan fungsi Badan Saniri Negeri pada penyelenggaraan

pemerintahan negeri di negeri Tulehu dan Suli, Kecamatan Salahutu Kabupaten Maluku Tengah. Keberadaan Badan Saniri Negeri diharapkan dapat membawa pembaharuan dalam penyelenggaraan pemerintahan dan pelaksanaan pembangunan pembangunan di negeri. Badan Saniri Negeri harus dapat berjalan sejajar dengan pemerintah desa dalam wujud kemitraan. Sebagai Badan Perwakilan yang terdiri atas pemuka-pemuka masyarakat yang ada di negeri, Badan Saniri Negeri mempunyai fungsi dalam melestarikan adat istiadat, menmpung dan menyalurkan aspirasi masyarakat, membuat peraturan negeri, dan mengawasi dan menetapkan Anggaran Pendapatan dan Belanja Negeri. Untuk itu perlu perlu peningkatan inisiatif, prakarsa dan peran aktif anggota Badan Saniri Negeri. Jika kondisi ini dapat terwujud maka penyelenggaraan

pemerintahan dan pembangunan di negeri berjalan sesuai dengan harapan dan keinginan masyarakat.

Proses rekruitmen anggota Badan Saniri Negeri ditentukan secara turun temurun, bukan didasarkan pada kualitas, dedikasi, loyalitas, kemampuan, kemauan dan kesempatan serta kesediaan sesorang. Melalui pola ketokohan berdasarkan keturunan dan lebih dekat dengan masyarakat terkadang mengalahkan warga masyarakat warga masyarakat yang secara akademik mampu untuk mewakilkan aspirasi masyarakat di negeri Tulehu dan Suli.

Badan Saniri Negeri adalah Perwakilan di tingkat desa, yang masih perlu pembinaan kepada para anggota Badan Saniri Negeri dari pemerintah daerah dan provinsi. Sayangnya dalam melakukan pembinaan, pemerintah dan instansi yang berwenang hanya dilakukan pada tahap awal dan kurang kontinyu, padahal mayoritas sumber daya manusia anggota Badan Saniri Negeri belum siap menjalankan fungsinya sesuai dengan yang di atur dalam peraturan perundang- 
undangan. Dampak dari kurangnya pemahaman anggota Badan Saniri Negeri terhadap tugas pokok dan fungsinya, menyebabkan kinerja dari Badan Saniri Negeri kurang maksimal. Keberadaan

Badan Saniri Negeri diharapkan dapat membawa pembaharuan dalam penyelenggaraan pemerintahan dan pelaksanaan pembangunan di negeri. Badan Saniri Negeri harus dapat berjalan sejajar dengan Pemerintah Negeri dalam wujud kemitraan. Sebagai badan perwakilan yang terdiri atas pemukapemuka masyarakat yang ada di negeri, Badan Saniri Negeri mempunyai fungsi antara lain menampung dan menyalurkan aspirasi masyarakat negeri. Untuk itu perlu peningkatan inisiatif, prakarsa dan peran aktif anggota Badan Saniri Negeri. Jika kondisi ini dapat terwujud, maka penyelenggaraan

pemerintahan di negeri dapat berjalan sesuai dengan harapan dan keinginan masyarakat.

faktor yang menyebabkan kinerja Badan Saniri Negeri kurang maksimal, yaitu : Anggota Badan Saniri Negeri tidak mendapat uang lelah/honor bulanan. Dalam Perda No 4 Tahun 2006, pasal 26 ayat (1) disebutkan dalam perda bahwa : "anggota Badan Saniri
Negeri dapat memperoleh tunjangan sesuai kemampuan keuangan negeri". Namun, kenyataannya sulit sekali karena kas negeri tidak mempunyai anggaran untuk itu. Sumber daya manusia kurang memadai, sehingga belum dapat menjabarkan tupoksi Badan Saniri Negeri. Pengalaman berorganisasi serta Sarana dan Prasarana.

Badan Saniri Negeri adalah bagian integral dari Pemerintah negeri akan berhadapan dengan kekuatan masyarakat yang cerdas dan kritis, oleh sebabnya perlu ada pembenahan mekanisme kerja organisasi, sikap dan prilaku kualitas dan kapabilitas anggota Saniri Negeri yang berorientasi terhadap kepuasan masyarakat yang diwakilkannya. Dan untuk menjamin terselenggaranya pemerintahan yang baik maka mutlak ada anggota yang berkualitas baik, hal ini ditentukan oleh tingkat pendidikan dan pengalaman organisasi anggota Badan Saniri Negeri. Demikian, maka menyarankan dalam merekrut anggota Saniri Negeri perlu diperhatikan tingkat pendidikannya, kualitas dedikasi, loyalitas, kemampuan, kemauan, dan kesempatan serta kesediaan seseorang tnnpa menghilangkan kearifan lokal yang sudah turun temurun 
menjadi keistimewaan yang perlu dipertahankan.

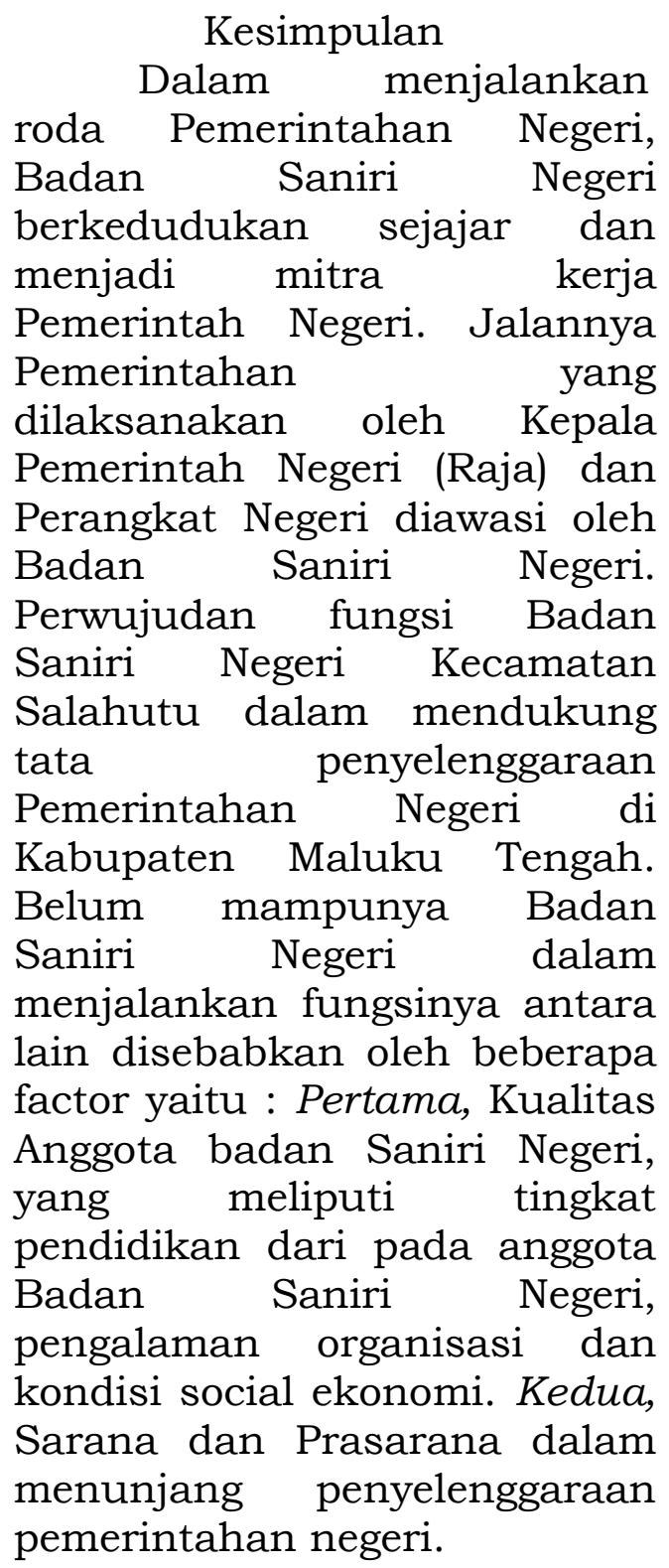

Bedasarkan kesimpulan di atas rekomendasi yang dapat dirumuskan adalah :

1. Untuk meningkatkan peran dan fungsi Badan Saniri Negeri, maka perlu dilakukan sosialisasi tentang eksistensi Badan Saniri Negeri, baik kepada anggota badan saniri negeri maupun masyarakat. Disamping itu perlu juga dipikirkan sarana dan prasarana kerja guna mendukung kelancaran kerja badan saniri negeri.

2. Untuk mewujudkan anggota Badan Saniri Negeri yang berkualitas, perlu dilakukan pemberdayaan dengan memberikan petunjuk petunjuk, bimbingan, pelatihan yang meliputi pengembangan sumber daya manusia, pengembangaan program teknologi informasi, pemantapan hak - hak dan kedudukan keuangan Badan Saniri Negeri, peningkatan kerja sama dengan lembaga masyarakat, serta peran serta masyarakat. 


\section{Daftar Pustaka}

Buku

AAGN Ari Dwipayana et. al. 2003. Membangun Good Governance di Desa. Yogyakarta: IRE Press.

. Pembaruan Pemerintahan Desa. 2003. Yogyakarta: IRE Press.

Analisis CSIS. 2004. "Relasi Kades - BPD di Era Desentralisasi dan Masa Depannya (Peran Masyarakat dan Demokrasi Lokal)". Jakarta: Lipi.

Beratha, N. 1992. Masyarakat Desa dan Pembangunan Desa. Jakarta : Ghalia Indonesia

Budiardjo, Miriam. 2000. Dasar-dasar Imu Politik. Jakarta: PT. Gramedia Pustaka Utama.

. 1996. Demokrasi di Indonesia. Jakarta: PT. Gramedia Utama.

. dan Ibrahim Ambong. 1995. Fungsi Legislatif Dalam Sistem Politik Indonesia. Jakarta : Raja Grafindo Persada.

Effendi, Ziwar. 1987, Hukum Adat Ambon Lease. Jakarta: PT Pradnya Paramita.

Napitupulu, Paimin. 2007. Menuju Pemerintahan Perwakilan. Jakarta: Alumni.

Ndraha, Taliziduhu. 1982.

- 1985. Pembangunan Desa dan Administrasi Pemerintahan Desa. Jakarta: Yayasan Karya Dharma.

.1991. Dimensi-dimensi Pemerintahan Desa. Jakarta: Bumi Aksara.

. 2000. Ilmu Pemerintahan, Jilid I - V, BKU-IP. Jakarta: IIP

. 2003a. Kybernology (ilmu Pemerintahan) Seri 1. Jakarta: Rineka Cipta.

Pito, Toni Andrianus, Efrizah dan Kamal Fasya. 2006. Mengenal Teori-Teori Politik, dari Sistem Politik Sampai Korupsi. Bandung: Nuansa. 
Sanit, Arbi. 1985. Perwakilan Politik Di Indonesia. Jakarta: Rajawali.

Suryaningrat, Bayu. 1981. Pemerintahan Dan Administrasi Desa. Jakarta: Beringing Trading Company.

Wijaja, Haw. 2001. Pemerintahan Desa/Marga Berdasarkan UU No 22 Tahun 1999 Tentang Pemerintahan Daerah. Jakarta: PT Raja Grafindo Persada,

Wasistiono, Sadu. 2003. Kapita Selekta Manajemen Pemerintahan Daerah. Bandung. CV Fokus Media.

. \& Irwan Tahir. 2007. Prospek Pengembangan Desa. Bandung: CV Fokus Media.

Yanuarti, S., Lan, T. J., Marieta, J. R., \& Tryatmoko, M. W. 2006. Kelembagaan

Pemerintah Lokal. Jakarta: LIPI.

- 2007.Kelembagaan Pemerintah dan Masyarakat Di Tingkat Lokal Dalam Pengelolaan Konflik di Maluku. Jakarta: LIPI.

Peraturan Perundang- Undangan

Undang-Undang Nomor 32 tahun 2004 tentang Pemerintahan Daerah.

Peraturan Pemerintah Republik Indonesia Nomor 72 Tahun 2005 Tentang Desa.

Peraturan Daerah Provinsi Maluku Nomor 14 Tahun 2005 Tentang Penetapan Kembali Negeri sebagai Kesatuan Masyarakat Hukum Adat Dalam Wilayah Pemerintahan Provinsi Maluku.

Peraturan Daerah Nomor 01 tahun 2006 Tentang Negeri

Peraturan Dearah Nomor 04 Tahun 2006 Tentang Pedoman Penataan Badan Saniri Negeri.

Sumber Lain

Kissya, Eliza. 2006. "Kewang Haruku". Melalui <www. Kewangharuku.org/eliza.html> [9/01/2012]

http://www.docstoc.com/docs/5935728/Sumartono---kemitraanpem-Desa-dan-BPD> [06/10/2012] 